\title{
Nonfamily knowledge during family business succession: a cultural understanding.
}

\author{
WASIM, J., CUNNINGHAM, J., MAXWELL-COLE, A., TAYLOR, J.R.
}




\section{Nonfamily knowledge during family business succession: a cultural understanding}

Purpose: Knowledge transfer plays a key role in the succession process. While much attention has been given to the passing of business knowledge form incumbent to successor, less is known about the use of non-family knowledge during this most crucial of family business events. This article looks to how knowledge from non-family employees is treated at times of succession. Importantly, it considers how the controlling family's cultural background may influence non-family knowledge use, and subsequent implications for the succession process.

Design/methodology/approach: An exploratory comparative case study design is adopted in order to uncover the complex social and cultural dynamics around knowledge use. Four case studies are presented from family businesses of different, and contrasting, cultural origins. Data were collected using semi-structured interviews, observations and formal secondary data from the organisations, all of whom operate in the UK.

Findings: Findings reveal a complex picture, part influenced by the cultural dynamics of the family, and part by business necessity. Specifically, power-distance appears as an informative cultural dimension, influencing how knowledge is used and non-family are perceived. While some family businesses privilege the knowledge from family, others see the need to build knowledge relationships more broadly.

Originality/value: This article provides further evidence to the heterogeneity of family businesses. It moves beyond a processual explanation of succession to develop a more contextually aware understanding of the dynamics and sensitivities involved.

Keywords: Knowledge transfer, Family business, Succession, Non-family, cultural background, case studies

Paper type: Research paper 


\section{Introduction}

Succession represents the most challenging time in the life of a family business, in terms of both business dilemmas and personal expectations. According to Brockhaus (2004), succession is a particularly complex process due to the number of difficult decisions made in order to ensure the business survives from generation to generation. As such, succession has dominated the minds of family business researchers in an attempt to build a robust understanding on the intricacies and nuanced perspectives of a multi-generational and passion-laden event in business development (Short et al., 2016). A triumphant "passing of the leadership baton from founder-owner to successor" (Handler, 1994, p. 134) is continually linked to the future performance of the firm and its continued viability in the eyes of various, and often contradictory, stakeholder positions (LeBreton-Miller et al., 2004).

A key implication of succession is the passing of knowledge from incumbent to successor (Cabrera-Suárez et al., 2001), the wisdom and intimate understanding of business functions must be shared to make transfer of power possible (Steier and Miller, 2010). This becomes particularly important in smaller businesses, where knowledge can be considered their single key resource (DeSouza and Awazu, 2006). However, small firms, due to their nature, typically hold knowledge in one or a few persons, which must be combined through socialised interaction in order to become a resource with strategic implications (Sirmon and Hitt, 2003). In this regard, family businesses may have the advantage of reciprocal and tightly trusting relationships, where tacit knowledge of the firm can flow easily (Lin, 2013). However, many studies have also noted meaningful heterogeneity in the ways in which family businesses approach the sharing of knowledge (Cunningham et al., 2016): contrasting those which build a social base throughout the firm with interdependence and experiential interaction (Pearson et al., 2008), with firms where knowledge is centralised, even shielded to input beyond the entrenched position of the family-based leader (Le Breton-Miller and Miller, 2006). This article looks to provide one form of explanation to the heterogeneous approaches to succession knowledge, by considering the controlling family's cultural background.

Inspiration is taken form a recent move in the broader entrepreneurship literature to consider contextual dynamics in entrepreneurial behaviour (Welter, 2011). Specifically, this study follows Danes et al. (2008) and looks to ethnic culture of the controlling family as an explanatory dimension in how knowledge is perceived at times of succession. Issues of cultural background take on an added significance when it comes to family business, as the values and beliefs of the family dominate business behaviour and decision making (Basu, 2004). While 
much has been said on the succession process, many works attempt to impose structured universalistic notions of staged approaches and intentions - normally form a westernised perspective (Daspit et al., 2016). While this body of work has made great progress in identifying the processes of succession (Nordqvist et al., 2013), this study moves beyond such an approach to explore the more nuanced psychological and emotional differences among family businesses (Filser et al., 2013; Gagné et al., 2014). By accessing the cultural background of the controlling family, the study uncovers a complexity of issues around familial expectations, succession intentions, and the perceptions of nonfamily stakeholders. The study asks the question: does cultural background impact on the way non-family knowledge is used at times of succession?

The key contributions of this article are two-fold. First, by focusing specifically on the use of knowledge from various stakeholder groups, the study addresses Bracci and Vagnoni's (2011) concern that such a crucial component is often neglected in more generalised discussions of succession processes; thus, casting further light on more micro-level aspects of the succession event. Second, by considering the influence of cultural context on the family's, and therefore the family business's approach to knowledge use, this article is able to uncover some of the more emotionally intricate drivers of family business behaviour. As such, the qualitative case study-based approach addresses some of the broader calls for more depth of understanding on family business behaviours and perceptions (Fletcher et al., 2016).

\section{Literature review}

\section{Stakeholder knowledge in succession}

While succession has a long and robust history in the family business literature, an increasing numbers of studies have started to turn their attention to the use of knowledge as an under acknowledged, though ultimately crucial, element in the succession process (Bracci and Vagnoni, 2011). As part of this movement, Mazzola et al. (2008) suggest that stakeholders, and in particular nonfamily stakeholders, play a vital role in the transfer of knowledge to bourgeoning successors.

Seminal writers in the knowledge management sphere (for example, Grant (1996) and Szulanski (1996)) have continually emphasised the complexity of transferring both tacit and explicit knowledge between management and stakeholders in a firm. Towards the goal of building a commonly-held knowledge in the firm, Grant (1996) indicates that the transfer of tacit knowledge from one employee to another can be very problematic, with Szulanski (1996) 
suggesting that a recipient's ability to absorb information is a fundamentally limiting factor. Much of this work has focused on the context of large organisations, where availability of resources make possible the development of knowledge management systems seeking to enhance the transfer of knowledge from one unit to another, along with mechanisms to smoothen the processes (Ghoshal and Bartlett, 1990; Nonaka and Takeuchi, 1995). However, far less attention has been paid to knowledge use in smaller firms (Nunes et al., 2006), where greater restrictions on resources mean knowledge flows are less systematic, and more rooted in the social relationships of the firm (Dotsika and Patrick, 2013; Durst and Edvardsson, 2012).

A more informal approach to knowledge use, in lieu of systematic management systems (McAdam and Reid, 2001), would seem particularly relevant for small family firms, where sharing networks and relationship complexities inform day-to-day behaviours (Lin, 2013; Pieper and Klein, 2007). To understand the implications of these complexities more clearly, LeBreton-Miller et al. (2004) point to succession as a focal event in which knowledge, and the flow of knowledge from incumbent to successor, becomes intensely sensitive to the social and cultural dynamics of the family business. Their model displays several ways in which the successor can be nurtured and developed in an attempt to promote prosperous succession, implying that in family businesses knowledge transfer from incumbent to successor usually begins in the home sphere and subtly builds over a protracted period of time. Cadieux (2007) also supports the key concern for incumbents of how to transfer their knowledge and networks to their replacement, explaining that many predecessors stay around the business long after succession has taken place to achieve this, positing knowledge transfer as a dyadic exchange between incumbent and successor.

However, other works advise that knowledge can come from other areas in the organisation, and is not necessarily family confined. Cunningham et al. (2017) suggest that there are multiple ways for a family business to approach knowledge. Mazzola et al. (2008) added to the academic discussion, suggesting a strategic planning phase to support a successful succession. Like Cabrera-Suárez et al. (2001), the authors place weight on the ability of the family business as an organisation to effectively design the transfer knowledge and skills to the successor, supporting the suggestion that a shared vision is developed by incumbent, successor and internal stakeholders to aid in the transfer of key knowledge to the successor. Thus supporting Royer et al.'s (2008) argument on the need for strong relationships amongst all employees to allow learning from the internal base of business-level knowledge. A point not lost on Cabrera- 
Suárez (2005) and Venter et al. (2005) when they discuss the role of non-family perception in relation to a successor's credibility and legitimacy.

While there has been significant research of the factors facilitating succession (for example, works on mentoring and the development of interpersonal skills (Distelberg and Schwarz, 2015; Chrisman et al., 1998)), this is often through a prism of successor choice and career intentions of offspring (Zellweger et al., 2011). At times, the successor's will to engage with the incumbent is brought to the fore (Sharma et al., 2001; Venter et al., 2005), while others consider generational differences in business approach (De Pontet et al., 2007). Only recently has the relational elements beyond individualistic expectations of incumbent and potential successor come into focus. For instance, Hatak and Roessl (2015) focus on relational competence and the importance of initiating and maintaining relationships throughout the business. This work seeks to further this understanding by focusing on knowledge-based theory and strategic development at the business-level, rather than at the individual (Cabrera-Suárez et al., 2001).

As part of the turn to present a more holistic view of knowledge use at times of succession, Daspit et al. (2016) assemble a social exchange perspective of succession in order to encompass a 'multiphase' and 'multistakeholder' approach, capable of dealing with various emotional and motivational implications (Long and Chrisman, 2014). Their review highlights that the vast majority of succession models align with LeBreton-Miller et al.'s (2004) phased approach, with social exchanges vital in all phases of the process. By adopting a social exchange perspective, knowledge is considered a resource exchanged through a generalised social interaction (Cropanzano and Mitchell, 2005), often influenced by ideas of altruism and stewardship (Davis et al., 2010; Schulze et al., 2001). Daspit et al. (2016) imply the context of the business can thus take on important meaning in terms of how knowledge is treated. However, our understanding of the succession event may not take into account the full contextual picture of social interactions, as much of the attention is given to a dyadic exchange between incumbent and successor. This study addresses this weakness by focusing on the use of knowledge from both within the incumbent/successor dyad, and out with, in terms of exchange with nonfamily stakeholders. The article pays particular attention to the importance of context as an informative factor on how social knowledge exchanges operate in the family firm. Specifically, the cultural background of the controlling family is used as a contextual reference point in building a cultural perspective on knowledge use at times of succession.

Cultural approaches to succession knowledge 
For some time now, family business researchers have understood the importance of cultural context in exploring business behaviours, with strong calls for greater cross-cultural understanding to ensure any theory development if not 'culturally bound' (Dyer and Sánchez, 1998). The result is that we now have many studies to compare and contrast family business behaviours across various national boundaries. For example, Corbetta and Montemerlo (1999), find family firms in Italy to carefully plan family succession, in an environment often closed to 'outsiders'. While Tatoglu et al. (2008) see incumbents in Turkey dominating much of the succession discussion, and retaining control over knowledge use, with an outcome favouring the male 'heir apparent' (Martin, 2001). Issues such as birth order (the persistence of primogeniture in both developed and developing worlds (Gilding et al., 2015)), perceptions on the importance of education, and approaches to gender are all found to be directly informed by the cultural context of the family business (Sharma and Rao, 2000). While environments change, and attitudes toward succession necessarily adapt, cultural differences still account for much of the variation found in family business behaviour (Sharma and Chua, 2013). Long and Mathews (2011) suggest that such culturally embedded attitudes will have particular impact on the generalised knowledge exchanges to and from non-family elements of the business, with knowledge routes often constrained by the religious and ethnic modal codes of family background (Janjuha-Jivraj and Woods, 2002). It is therefore important that any study of knowledge use during succession takes such cultural difference into account.

In order to investigate knowledge use during succession from a cultural perspective, this study adopts the much-utilised framework of Hofstede (1980, 2001), which articulates various cultural dimensions through which individuals may approach problems, such as knowledge use at times of succession. Though this framework, and archetypal frameworks on culture in general, are heavily criticized for imposing overly simplified definitions on what is a complex and multi-faceted social construction (Fougère and Moulettes, 2007; McSweeney, 2002; Shaiq et al., 2011), it remains well-referenced in the family business literature as a useful guiding framework to discussions on variations in cultural approach (Denison et al., 2004; Sharma, 2004; Vera and Dean, 2005; Yan and Sorenson, 2006). In this study, the intention is not to apply Hofstede's cultural dimensions as a way to define one culture relative to another, but instead only to gain a comparable understanding on some of the social norms evident in family business decision making. Thus, rather than assuming a set cultural definition on the background of the controlling family, the members of the business have themselves been asked to interpret the cultural dimensions of their organisation. 
A crucial aspect which sets this work aside from others considering cultural context, is that it looks to businesses with differing cultural family background, but who are trading in the same operating environment. While the common institutional framework of the UK offers a steady economic and political setting, the four cases presented involve controlling families from differing cultural backgrounds. In this way, the work investigates issues of cultural and ethnic embeddedness in the family business (Granovetter, 1985; Kloosterman et al., 1999). With ethnic minority businesses, heightened meaning is often ascribed to internal cultural and familial dynamics as a reaction to the 'outside' institutional forces (Adendorff and Halkias, 2014). The willingness of firms to reject parochial interests when in contrasting environments is often pulled into question (Ram and Jones, 2008), thus the cultural influences are more explicated and therefore clearer to investigate in terms of their implications for knowledge use during succession.

\section{Methodology}

An exploratory comparative case study approach is adopted, providing a depth of understanding to allow for the emotional complexity of succession to surface. Case study research involves multiple sources of evidence collected within the workplace and can explore both current issues in the business or, importantly, historical influences (Jankowicz, 2005). Yin (2014) proposes that case studies provide in-depth insight, particularly when focused around a certain phenomenon. In this article, multiple sources of evidence (for example, interviews, documentation and participant observation) are used to interpret the use of nonfamily knowledge during the succession event. Multiple cases are used in order to contrast and compare succession in family businesses from different cultural backgrounds.

\section{Sample}

Four cases of post-succession family-owned SMEs were selected, where the business had recently been through a family succession process. The sample is from the UK, which controls for the specificities of operating environment and allows isolation of the influence of cultural background of in controlling family. Eisenhardt (1989) suggests that fewer case studies allow for greater depth of interpretation and exploration of the themes. While limited in terms of generalisability, this allows the analysis to investigate the often-tacit influence of cultural background on the emotions and behaviours of the business. 
From this point onwards, family-controlled SMEs of the sample are referred to as cases associated with the cultural background of the family. Non-probability sampling (Cooper and Schindler, 2014), often used in conducting case study approaches, allowed for the purposeful sampling of four UK-based businesses from distinct cultural backgrounds. The intention is to present cases representing cultural backgrounds considered to be disparate, broadly along lines of Hofstede's (1980) cultural dimensions. As such, a form of theoretical sampling was used in order to identify suitable cases to satisfy the variety of cultural backgrounds required. The final sample contains cases from the Middle East, Far East, Asia and Europe. The details of the four cases are presented in Table 1.

\begin{tabular}{c|c|c|l|l}
$\begin{array}{c}\text { Company } \\
\text { reference }\end{array}$ & $\begin{array}{c}\text { Time since } \\
\text { succession }\end{array}$ & $\begin{array}{c}\text { Number of } \\
\text { Employees } \\
\text { family members) }\end{array}$ & \multicolumn{1}{|c|}{ Industry } & \multicolumn{1}{|l}{ Family Origin } \\
\hline AUT & 5 Years & $32(5)$ & $\begin{array}{l}\text { Automobile } \\
\text { Repair }\end{array}$ & $\begin{array}{l}\text { United Arab } \\
\text { Emirates }\end{array}$ \\
\hline RST & 4 Years & $12(4)$ & Restaurant & China \\
\hline NWS & 9 Years & $107(5)$ & News and Media & Pakistan \\
\hline SPR & 1 Year & $7(5)$ & $\begin{array}{l}\text { Automobile Spare } \\
\text { Parts }\end{array}$ & United Kingdom \\
\hline
\end{tabular}

Table 1: Case study organisations

\section{Participants}

In each of the cases, participants included both, the successor, the predecessor (father and son in all cases), and at least one other key nonfamily employee of the business. Such breadth of participant perspective allows the work to uncover the multiple issues and emotions of the process, building a more robust picture than when considering the successor/incumbent alone. Such a holistic approach is a key strength of this article, and addresses many concerns in the family business literature of an over emphasis on controlling family stakeholders, to the neglect of non-family (Xi et al., 2014). This led to a total of 14 interviews, with at least three informing each case. All participants were assured that their data were treated with the utmost confidentiality at all stages of the research and that all information is anonymised. After the interviews, a short summary of the findings was prepared and verified by the participants to strengthen reliability. Participants were only provided with the summary of their own interview, not the entire case of their particular business. 
Relevant details of participating individuals from their respective family-controlled SMEs are outlined in Table 2.

\begin{tabular}{c|c|c|c|c}
$\begin{array}{c}\text { Company } \\
\text { reference }\end{array}$ & Interviewee 1 & Interviewee 2 & Interviewee 3 & Interviewee 4 \\
\hline AUT & Successor (SSR1) & $\begin{array}{c}\text { Predecessor } \\
\text { (PDS1) }\end{array}$ & $\begin{array}{c}\text { Nonfamily manager } \\
\text { (MGR1) }\end{array}$ & $\begin{array}{c}\text { Nonfamily mechanic } \\
\text { (MHN1) }\end{array}$ \\
\hline RST & Successor (SSR2) & $\begin{array}{c}\text { Predecessor } \\
\text { (PDS2) }\end{array}$ & $\begin{array}{c}\text { Nonfamily manager } \\
\text { (MGR2) }\end{array}$ & - \\
\hline NWS & $\begin{array}{c}\text { Successor } \\
\text { (SSR3) }\end{array}$ & $\begin{array}{c}\text { Predecessor } \\
\text { (PDS3) }\end{array}$ & $\begin{array}{c}\text { Nonfamily finance } \\
\text { director (FDR3) }\end{array}$ & $\begin{array}{c}\text { Nonfamily editor } \\
\text { (EDR3) }\end{array}$ \\
\hline SPR & Successor (SSR4) & $\begin{array}{c}\text { Predecessor } \\
\text { (PDS4) }\end{array}$ & $\begin{array}{c}\text { Nonfamily manager } \\
\text { (MGR4) }\end{array}$ & - \\
\hline
\end{tabular}

Table 2: Participants

\section{Data collection}

De Massis and Kotlar (2014) advise that the main potential of a case study approach can be achieved via the collection and integration of data collected via multiple means - as opposed to qualitative data analyses alone. For this research; semi structured interviews, participant observations and documentary secondary data from the organisations were analysed to develop cases. Primary data collection took place during late 2016 and early 2017 over a period of 3 months.

Before each qualitative interview took place, the participant was presented with an information sheet providing the necessary details surrounding the research, the opportunity to raise any concerns they might have and to give their consent. Most interviews took place at the business location; however, three participants chose to talk at a nearby coffee shop. During each interview, only the researcher and the participant were present.

As part of this analysis, and in order to access the implications of each case's cultural background, an iterative process of reflection on cultural dimensions took place. Key participants - successor and at least one employee - were presented with Hofstede's (1980) four main dimensions of culture and asked to score their organisations along each dimension on a range of 1-5 (individualism-collectivism; power distance low-high; uncertainty avoidance low-high; and masculinity-femininity). However, in order to avoid self-completion bias, and 
also to engage with the participant in more depth, each individual was asked to explain their scoring. This part of the analysis is in no way intended to provide quantified and definitive conclusions on cultural background, but is instead used to prompt reflection and offer a useful frame within which to discuss cultural implications. Any scoring presented in the analysis represents aggregate scores using successor, employee, and observation data.

Secondary documentary evidence from the organisations compliments the primary data, and are used in conjunction with the interviews and researcher observations to produce each case study. Analysis looks to integrate the combine sources of data and consider the emergence of themes and patterns within and between the cases (Braun and Clarke, 2006). The four cases studies are presented separately, with an integrating discussion to address the key findings of the work and pull out the main themes found in the data. A summary of the key findings is also provided in Table 3.

\section{Case study findings}

\section{Case one - United Arab Emirates}

AUT is a family-owned automobile repair business, the founder originally migrated to the UK from the UAE in early 1990s and started the business in 1995 in London. 32 currently work in the business, including 5 family members. It was the intention of the founder, from an early point, that his son would take over the business, and for that reason the eventual successor was immediately involved in the organisation from an early age, and was sent to college to be trained as an MOT tester as well as getting further qualifications in the automobile industry.

As a result, the successor son was involved in the business from sometime, working alongside his father in addition to gaining experience in every area of the business over the course of years. Is such a sense, the succession process took place over the entirety of the son and father working together. A nonfamily mechanic suggests that employees "love to work with him [son successor] because he works alongside them" (MHN1), indicating that a closeness between employees and successor is important. A managerial-level nonfamily employee mentioned that it was not unexpected when succession happened, as they had seen him working with them and they fully accepted that one-day the son would take charge of the business.

It was also recognised by the founder that although employees were not involved in the process and discussions around succession, if the majority of employees would have responded 
negatively it could have been an immensely stressful scenario and the business would have suffered significantly.

Cultural dimensions were found to be in favour of collectivism, and employees supported this as they believed that owners listened to their ideas and had a say in decision-making, a notion reinforced by the successor-son also. There was minimal power-distance, believed to be driven by the nature of the business, it was highlighted by employees and family that taking un-certain risk could be catastrophic - so avenues of communication to family were important. This was an approach rationalised by the founder in that "to survive in any business, one needs to have open communication and you need to take care of each other. ...everyone in a business plays an essential role but sometimes you reach a point that you cannot make everyone happy, you have to say no to people, but they understand it, mostly” (PDS1).

\section{Case two - China}

RST is a family-owned Chinese restaurant founded in 2003, the same year in which the family immigrated to the UK from China. Initially started by the founder, with his wife and brother as employees, the restaurant now has 12 employees. In 2014 the founder handed over the business to his eldest son and withdrew from the business to start another separate independent restaurant in a nearby town. The eldest son successor did not move with the family to the UK, but joined them later in 2013 to begin working in the restaurant.

Although the founder's eldest child was his daughter, with a university degree in management, according to the successor (SSR2) their culture meant "it [was] obvious that eldest son would one take the place of the father, so it was not a surprise for the people who worked there". This notion was reinforced by the non-family manager also. The reaction from the employees was minimal, as the eventual successor started working in the business a year before succession, all in the organisation knew, and accepted that he was being groomed for succession.

The founder suggests involvement of non-family in decision-making processes is negligible, and it was acknowledged by both controlling family and employees that, though the business needed them, if something were to arise non-family could easily be replaced by someone else. In this sense, the business operated with a more individualistic culture, rather than collective particularly based on the individual control and drive of the founder. Employees were not encouraged to take initiative or to involve themselves in advising management. The controlling family believe that broader knowledge use is not necessary, due to the stable nature of the industry. 
NWS is a third-generation family business. The current owner's grandfather started the company in early 1970s when he moved to the UK from Pakistan, before passing it over to his son in 1992, who done the same to pass on to the current owner in 2006. With over 100 current employees, NWS is the largest of the four cases presented, and has 5 family members including a brother, sister and two uncles of the owner. A graduate of Bachelors and Masters level education (reading an industry-specific discipline), this attention to learning was highlighted by the owner's father and predecessor, "I wanted my son to learn about the business from the business and about the overall industry from his education" (PDS3). He further suggests that this was not just his wish, but also a specific interest of his son when he started to show interest in the business.

Most non-family employees accepted that succession would happen within the family, only unsure whether it would be the elder son or the younger to take over, so when succession took place there were no surprises for the rest of the organisation. One high-level non-family employee mentioned that he "thought it would be the younger son because when he used to come to work with his father and brother he used to show more curiosity and interest in things, but we loved both of them equally as we saw them growing up in front of us, so we were happy for the transition" (EDR3). To support knowledge transfer among all organisational members, NWS adopts an online system where employee and company data are stored and shared with relevant internal members. This system is also said to have aided the succession process, as the successor did not have go through people to find relevant information.

Distance between the employees and management is believed to be minimal, with employees involved in all major decisions. Family management is in favour of employees taking initiative in proposing and attempting innovative practices. Both, predecessor and successor recognised the value, stake and influence non-family employees had in the business and they both agreed that if the employees were not heard the business would suffer massively. They also highlighted that if the employees were to hold grievance with any part of the succession process, even choice of successor, it could have significantly impacted on the business.

\section{Case four - United Kingdom}

SPR is an automobile parts supplier and distributor. This case provides a family of UK background to contrast the ethnic minority backgrounds of previous cases. The company was started in the early 2000s and succession took place in 2016. From the beginning the business 
was dominated by family members, with only two out of seven current employees non-family. Yet it is believed that non-family members have a strong role to play in running the business. Succession occurred when the founder was diagnosed with a long-term illness and no one, family or non-family, aside from his son, was willing to take over. A non-family manager in the business explained, "I know this business inside out ... I do not want myself to engage in the running of the business, which I had to do briefly, when he (son successor) stepped up it was a relief for me" (MGR4). Since succession, the business is run by the founder's son, his partner, and three other siblings working in the business.

The recent successor to the business points to the importance of the previously mentioned nonfamily manager, claiming that "he (non-family manager) is one of the most technical people in the business, without him we would lose a lot, we are still learning from him... if he quits, we might not close down but definitely slowdown" (SSR4).

To gain experience and knowledge, and in a way to compensate for his reliance on other nonfamily employees, the successor purposefully attended university to gain a management degree. While studying, he also acted as an intern at the business, to strengthen his understanding of academic knowledge in practice. This knowledge and involvement with the business afforded him the confidence to communicate with non-family stakeholders, in order to facilitate the transfer of further knowledge, more specific to the business. It seems that not only was there little power distance between the family and non-family employees here, but in many ways, there was deference toward the other employees, who he felt had greater business knowledge. This may be a symptom on the size of the organisations, but both current owner and predecessor noted an active encouragement of employees to share ideas or raise concerns to the benefit of the business' operations. 


\begin{tabular}{|c|c|c|c|c|c|c|c|}
\hline Case & 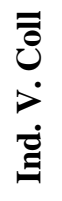 & $a$ & 总 & 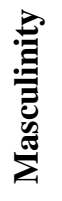 & $\begin{array}{l}\text { Knowledge acquisition for a } \\
\text { successor }\end{array}$ & $\begin{array}{l}\text { Reaction to succession from non- } \\
\text { family }\end{array}$ & $\begin{array}{l}\text { Role of non-family and their } \\
\text { knowledge. }\end{array}$ \\
\hline AUT & 4 & 2 & 2 & 3 & $\begin{array}{l}\text { Successor qualified as an MOT tester in } \\
\text { addition to attending college for } \\
\text { automobile mechanic courses. "I } \\
\text { worked alongside my dad, managers at } \\
\text { each location and with mechanics" } \\
\text { (SSR1). }\end{array}$ & $\begin{array}{l}\text { As the family successor was groomed to } \\
\text { take over the business, the reaction from } \\
\text { the employees was not unexpected or } \\
\text { negative at all. "We love to work with } \\
\text { him because he [already] works with } \\
\text { us" (MHN1). }\end{array}$ & $\begin{array}{l}\text { While they were not involved directly, } \\
\text { there is clear acknowledgement that } \\
\text { sensitivity is required, and non-family } \\
\text { will of succession is crucial. }\end{array}$ \\
\hline RST & 1 & 5 & 5 & 1 & $\begin{array}{l}\text { Family successor only started working } \\
\text { at the business one year before } \\
\text { succession, to know the business and } \\
\text { people that are working there but did not } \\
\text { gain any formal qualification related to } \\
\text { that business. }\end{array}$ & $\begin{array}{l}\text { The founder claims, "in our culture, it is } \\
\text { obvious that eldest son would take the } \\
\text { place of the father, so it was not a } \\
\text { surprise for the employees" (PDS2), } \\
\text { aligning with the view of all participants } \\
\text { for this organisation. Reaction from the } \\
\text { employees was not unexpected or in any } \\
\text { way negative. }\end{array}$ & $\begin{array}{l}\text { The role of non-family stakeholders in } \\
\text { the business and their knowledge about } \\
\text { it was minimal. Non-family } \\
\text { stakeholders are considered a business } \\
\text { requirement but seen as eminently } \\
\text { replaceable - in contrast to family } \\
\text { members. }\end{array}$ \\
\hline NWS & 5 & 2 & 3 & 5 & $\begin{array}{l}\text { Family successor started working at the } \\
\text { business straight after high-school and } \\
\text { later gained a Master's degree in Mass } \\
\text { Communication while engaging } \\
\text { directly with the organisation, his father } \\
\text { stating, "I wanted my son to learn about } \\
\text { the business from the business" (PDS3). }\end{array}$ & $\begin{array}{l}\text { According to all participants, most } \\
\text { employees knew the from that } \\
\text { succession would take, and had an } \\
\text { expectation of it. "I thought it would be } \\
\text { the younger son because... he used to } \\
\text { show more curiosity." (EDR3). }\end{array}$ & $\begin{array}{l}\text { Non-family knowledge held in high } \\
\text { regard. "We have over hundred people } \\
\text { working here, and I cannot practically } \\
\text { know everything they know, and I have } \\
\text { to rely on their knowledge" (SSR3). } \\
\text { Coming from the founder's view that, } \\
\text { "your success and failure are based on } \\
\text { how good of a team you have". }\end{array}$ \\
\hline SPR & 4 & 1 & 2 & 4 & $\begin{array}{l}\text { Family successor was involved in the } \\
\text { business from the very beginning. "I } \\
\text { learnt the practicality of the business by } \\
\text { being in the business and learnt about } \\
\text { the macro environment by going to the } \\
\text { university and studying management" } \\
\text { (SSR4) }\end{array}$ & $\begin{array}{l}\text { Within family, succession occurred due } \\
\text { to there being no other willing } \\
\text { alternatives from non-family. }\end{array}$ & $\begin{array}{l}\text { Both founder and successor } \\
\text { acknowledge that non-family } \\
\text { knowledge is an asset. To the extent of } \\
\text { a fearful reliance on one specific non- } \\
\text { family employee in particular. }\end{array}$ \\
\hline
\end{tabular}

Table 3: Case data summary 


\section{Discussion and interpretation}

Though all of the cases here liked to believe they were collectivist in nature, findings suggest that some of the cultural assumptions ingrained in the business dictated how this collective approach happens, or more accurately, who is considered important to be part of the collective. For instance, in case two, there appears a collective approach while dealing with those external to the business: suppliers, customers, even competitors, but a far more distant approach when dealing with internal employees who were not of family relation. Much of this situation echoes previous research on the expectations of businesses from Chinese backgrounds to operate politically and embed in networks of organisations (Brautigam, 2003; Cong et al., 2017; Shi et al., 2015; Shi and Dana, 2013), however, this exchange from external knowledge sources may not translate to an internal knowledge socialisation.

This contrasts with case three, where the largest of the organisational cases presented appears to involve knowledge from all employees at every stage of the succession process. Due to the size of the firm, the knowledge processes were systemised (following Nonaka and Takeuchi, 1995). Culturally, the participants in this case considered the organisation to hold a very low power-distance, thus a route for knowledge transfer was expected, regardless of familial status - while in case two it is acknowledged that a high power-distance is purposefully maintained. However, this distance does not appear to be hierarchal alone, but aligned directly to familial relations. For instance, in case two participants recount a situation where two similar ideas to improve ordering systems are presented, one from non-family and the other from family. The recommendation of familial origin was the one taken forward. Suggesting a weight, or privilege, given to family knowledge over business knowledge in cultures based on greater power distance.

Those cases attempting to balance cultural dynamics imply that "material goals as well as relationships [are necessary], without one, the other is pointless" (SSR1) - pointing to Hofstede's masculinity/femininity discussions. However, findings from case three suggest that, while a feminine relationship-based culture is the ideal (informed from their cultural heritage) and that "when you have that level of commitment from the employees you can have more trust in them" (PDS3), all in the organisation acknowledged that non-family were good when 
needed, but at times of crisis, they became the most expendable. Perhaps suggesting that the cultural ideal can only hold when the business realties allow them to.

In those cases, with lower power-distance the need to 'reach out' to all others in the organisation is made clear. Each of these successors looked to showcase their work ethic to the other employees, seeking some form of acceptance, or even respect (mirroring Hatak and Roessl's (2015) notion of relational competence). In case three, this is perhaps most clearly illustrated: "it is sometimes hard to be the son of the boss, you always find people that think that you got everything just because of your bloodline whereas it is not entirely true. I did a get an opportunity by being my father's son, but I have worked in every area of the business from top to bottom." (SSR3). In case two, which constructed a much higher power-distance, and familial priority, the eventual successor only entered the organisation one-year prior to taking over as owner. However, due to the cultural dynamics informing the status and power of family, this does not impact on their ability to command legitimacy in the business.

The contrasting findings here begin to challenge the long-held suggestion that a fully committed successor is critically important in promoting a successful succession (Chrisman et al., 1998). For those businesses where cultural collectivism and more equitable levels of power relations are important, then a socialisation of a committed successor would indeed appear a prerequisite to knowledge acquisition; exemplified in case three, where the eventual successor son was to learn 'about the business from the business' and fully commit to the firm and its varied internal stakeholders so as to stave off any problematic grievance in his ascension. However, this is not the situation of case two, and, it could be argued, is not the situation in case four where the son only takes on the business as a last resort. A committed successor may then be a product of specific cultural dynamics, rather than a structural necessity of succession success.

A final differentiating aspect of the cases presented is in approach to formalised and practical education. While each successor expressed that working in their family business had helped them acquiring knowledge which they later used in the business, some put greater emphasis on how this was achieved than others. In some cases, knowledge gained from and about the business seems to be coupled with presence and legitimisation of their place in the firm. As mentioned, in those cases where knowledge is not so centralised, respect of internal non-family stakeholders appears critical to acquiring business understanding. Whereas in other firms, more 
centralised around the family, it seems knowledge, formal or practical, is less relevant than the familial relationship with the founder/predecessor.

\section{Conclusion}

Moving focus away from a processual understanding of family business succession (Nordqvist et al., 2013) and towards a culturally sensitive and contextual approach to social exchange (Danes et al., 2008; Daspit et al., 2016) allows this study to contribute to the literature in two ways. First, the findings make it clear that use of knowledge from nonfamily stakeholders may not be as open and available to successors as theoretical approaches to knowledge sharing would hope for. Sensitivity around the role of nonfamily, and their more transient nature in the firm, means that their knowledge is valued highly, and careful consideration is given to how they react to and engage in the succession process. Sensitivity around nonfamily is also felt by the family successors themselves. This appears to be manifest in an acute awareness that family successors must 'prove themselves' to nonfamily employees. However, the way in which this is perceived varies in the cases presented, from full engagement with nonfamily during each succession stage, to a more limited engagement based on conflict limitation and required information only.

Second, by viewing cases along cultural lines, the findings suggest a contextual explanation to the variety of approach to nonfamily at times of succession (Randerson et al., 2015). The family is considered a vehicle for cultural values, which directly informs motives and decision-making within the business (Seaman et al., 2015). From this assumption, the study sought to investigate the implications of a variety of cultural backgrounds, operating within a seemingly common institutional framework in the UK. The findings suggest that cultural norms can, and do, extend national boundaries to influence how succession is managed. In particular, nonfamily stakeholders are used and incorporated on very different terms when it comes to succession, with cultural background highlighted as an explanation, even justification, for the business approach. In this regard, it seems that the behaviours of family businesses are less informed by the structural setting, but more by the latent and socially constructed influences within the family's intimate relationships. However, that is not to say that the family business must be defined by the family's cultural background. Instead, the findings suggest that some aspects of cultural background impact more than others, therefore it may be more the collision of cultural background with the institutional setting of the 'host' country or industry, which generates a 
unique and asymmetrical approach (Javidan et al., 2006), thus contributing in some way to our understanding of cultural dimensions more generally.

It is clear that both predecessor and nonfamily knowledge represent equally important aspects of the succession process. However, the cultural background of the family influences how this knowledge exchange occurs. In particular, high power-distance (to borrow a Hofstede (1980) phrase) harvests a more divisive atmosphere, restricting specific sharing to the incumbent/successor dyad. In these more 'power distant' cases, knowledge transmission only takes place when particular information is sought. In other cases, successors and predecessor were more adept at acquiring generalised knowledge from each other and the organisation more broadly. Thus, cultural background and inclination can directly impact on the learning options available through the succession process (Jaskiewicz et al., 2016).

There are a variety of mechanisms that a successor can use to facilitate generalised and restricted exchanges with internal non-family stakeholders, in aiding the succession process. While the use and goodwill of nonfamily employees emerges as a theme in each of the successions presented, the nature of this relationship seems to, again, be a product of power distance in the business. From the empirical evidence, it is clear that the most vital knowledge and experience for successors is gained during their nurturing and development, before the event of succession. While, engagement with nonfamily can help the successor embed themselves in the business and show a committed character (LeBreton-Miller, Miller and Steier, 2004), in firms where more power distance is evident, this aspect becomes less important.

\section{Limitations and future research}

This article addresses calls from Daspit et al. (2016) to provide broader understanding of the social exchange relationships deemed crucial at times of family business succession. While much has been done to illuminate the role of nonfamily stakeholder knowledge, and the varying cultural approaches to it, the work cannot claim to have been comprehensive in its approach to cultural background, looking instead to provide in-depth insight on carefully selected cases. Future work may look to be more systematic in the cultural backgrounds investigated, in order to establish the commonalties and differences among cultural groups, or more ethnic understandings of family businesses dynamics. 
Moreover, this article intentionally focuses on socialised knowledge exchanges from nonfamily employees. However, the forms of knowledge applicable to the succession process are many and various. Future studies may look to consider the other, less categorical, sources of knowledge drawn upon by family business successor, such as the influence of peer groups, social relationships outside of the businesses, and understandings from the narratives of business and entrepreneurship more generally. This may be particularly interesting for businesses such as those presented here, where there is a meeting of two cultures: culture of the operating environment and culture of family background, with two potentially competing entrepreneurial narratives.

Finally, as with all case-based studies, the findings here are methodologically limited in their generalisability and cross-sectional nature. In particular, calls for more longitudinal studies are supported by this article's findings. Future research would do well to consider how the use of knowledge is developed through time, particularly as a key theme of this case data has shown succession knowledge to be passed from very early on in the founder-successor relationship. A further methodological consideration may be in sampling approach. The largest organisational case represented here demonstrates knowledge sharing to successor with relative ease, pointing to a strong knowledge management 'system'; echoing a ghost of family business literature past - where emotional family is pitted against systematic professionalism. Future studies may look revisit the professionalization argument in light of the role of cultural background. Evidence here would suggest larger family businesses benefit from systematic approach, perhaps overcoming the emotional and cultural baggage of family background as the organisation develops.

\section{References}

Adendorff, C. and Halkias, D. (2014), "Leveraging ethnic entrepreneurship, culture and family dynamics to enhance good governance and sustainability in the immigrant family business", Journal of Developmental Entrepreneurship, Vol. 19 No. 2, pp.

Basu, A. (2004), "Entrepreneurial aspirations among family business owners: an analysis of ethnic business owners in the UK", International Journal of Entrepreneurial Behavior \& Research, Vol. 10 No. 1/2, pp. 12-33.

Bracci, E. and Vagnoni, E. (2011), "Understanding Small Family Business Succession in a Knowledge Management Perspective.”, IUP Journal of Knowledge Management, Vol. 9, pp. $7-36$. 
Braun, V. and Clarke, V. (2006), "Using thematic analysis in psychology", Qualitative Research in Psychology, Vol. 3 No. 2, pp. 77-101.

Brautigam, D. (2003), "Close Encounters: Chinese Business Networks As Industrial Catalysts in Sub-Saharan Africa", African Affairs, Vol. 102 No. 1, pp. 447-467.

Brockhaus, R.H. (2004), "Family Business Succession: Suggestions for Future Research", Family Business Review, Vol. 17 No. 2, pp. 165-177.

Cabrera-Suárez, K. (2005), "Leadership transfer and the successor's development in the family firm”, Leadership Quarterly, Vol. 16 No. 1, pp. 71-96.

Cabrera-Suárez, K., De Saá-Pérez, P. and García-Almeida, D. (2001), “The succession process from a resource-and knowledge-based view of the family firm", Family Business Review, Vol. 14 No. 1, pp. 37-46.

Cabrera-Suárez, K., De Saá-Pérez, P. and García-Almeida, D. (2001), “The succession process from a resource-and knowledge-based view of the family firm", Family Business Review, Vol. 14 No. 1, pp. 37-46.

Cadieux, L. (2007), "Succession in Small and Medium-Sized Family Businesses : Toward a Typology of Predecessor Roles During and After Instantement of the Successor", Family Business Review, Vol. 20 No. 2, pp. 95-109.

Chrisman, J.J., Chua, J.H. and Sharma, P. (1998), "Important attributes of successors in family businesses: An exploratory study”, Family Business Review, Vol. 11 No. 1, pp. 35-47.

Cong, C., Dempsey, M. and Xie, H.M. (2017), "Political skill, entrepreneurial orientation and organizational justice", International Journal of Entrepreneurial Behavior \& Research, Vol. 23 No. 1, pp. 20-34.

Cooper, D.R. and Schindler, P.S. (2014), Business Research Methods, 12th ed., McGraw-Hill Education.

Corbetta, G. and Montemerlo, D. (1999), “Ownership, governance, and management issues in small and medium-size family businesses: A comparison of Italy and the United States", Family Business Review, Vol. 12, pp. 361-374.

Cropanzano, R. and Mitchell, M.S. (2005), "Social exchange theory: An interdisciplinary review", Journal of Management, Vol. 31, pp. 874-900.

Cunningham, J., Seaman, C. and McGuire, D. (2016), "Knowledge sharing in small family firms: A leadership perspective", Journal of Family Business Strategy, Vol. 7 No. 1, pp. 3446.

Cunningham, J., Seaman, C. and McGuire, D. (2017), "Perceptions of Knowledge Sharing Among Small Family Firm Leaders: A Structural Equation Model”, Family Business Review, Vol. 30 No. 2, pp. 160-181.

Danes, S.M., Lee, J., Stafford, K. and Heck, R.K.Z. (2008), “The effects of ethnicity, families and culture on entrepreneurial experience: An extension of sustainable family business theory", Journal of Developmental Entrepreneurship, Vol. 13 No. 3, pp. 229-268. 
Daspit, J.J., Holt, D.T., Chrisman, J.J. and Long, R.G. (2016), "Examining Family Firm Succession From a Social Exchange Perspective: A Multiphase, Multistakeholder Review", Family Business Review, Vol. 29 No. 1, pp. 44-64.

Davis, J.H., Allen, M.R. and Hayes, H.D. (2010), "Is blood thicker than water? A study of stewardship perceptions in family business", Entrepreneurship Theory and Practice, Vol. 34, pp. 1093-1116.

De Massis, A. and Kotlar, J. (2014), "The case study method in family business research: Guidelines for qualitative scholarship”, Journal of Family Business Strategy, Vol. 5 No. 1, pp. $15-29$.

De Massis, A. and Kotlar, J. (2014), "The case study method in family business research: Guidelines for qualitative scholarship", Journal of Family Business Strategy, Vol. 5 No. 1, pp. 15-29.

De Pontet, S.B., Wrosch, C. and Gagne, M. (2007), "An exploration of the generational differences in levels of control held among family businesses approaching succession", Family Business Review, Vol. 20 No. 4, pp. 337-354.

Denison, D., Lief, C. and Ward, J.L. (2004), "Culture in family-owned enterprises: recognizing and leveraging unique strengths", Family Business Review, Vol. 17 No. 1, pp. 61-70.

Desouza, K.C., and Awazu, Y. (2006), "Knowledge management at SMEs: five peculiarities", Journal of Knowledge Management, Vol. 10 No. 1, pp. 32-43.

Distelberg, B.J. and Schwarz, T.V. (2015), "Mentoring Across Family-Owned Businesses", Family Business Review, Vol. 28 No. 3, pp. 193-210.

Dotsika, F. and Patrick, K. (2013), "Collaborative KM for SMEs: a framework evaluation study”, Information Technology \& People, Vol. 26 No. 4, pp. 368-382.

Durst, S. and Edvardsson, I.R. (2012), "Knowledge management in SMEs: a literature review", Journal of Knowledge Management, Vol. 16 No. 6, pp. 879-903.

Dyer Jr, W. and Sánchez, M. (1998), "Current state of family business theory and practice as reflected in Family Business Review 1988-1997”, Family Business Review, Vol. 11 No. 4, pp. 287-295.

Eisenhardt, K.M. (1989), "Building theories from case study research", Academy of Management Review, Vol. 14 No. 4, pp. 532-550.

Filser, M., Kraus, S. and Märk, S. (2013), "Psychological aspects of succession in family business management”, Management Research Review, Vol. 36 No. 3, pp. 256-277.

Fletcher, D., De Massis, A. and Nordqvist, M. (2016), “Qualitative research practices and family business scholarship: a review and future research agenda", Journal of Family Business Strategy, Vol. 7 No. 1, pp. 8-25.

Fougère, M. and Moulettes, A. (2007) "The construction of the modern west and the backward rest: studying the discourse of Hofstede's culture's consequences", Journal of Multicultural Discourses, Vol. 2 No. 1, pp. 1-19. 
Gagné, M., Sharma, P. and De Massis, A. (2014), "The study of organizational behaviour in family business", European Journal of Work and Organizational Psychology, Vol. 23 No.5, pp. 643-656.

Ghoshal, S. and Bartlett, C.A. (1990), "The Multinational Corporation as an Interorganizational Network.", Academy of Management Review, Vol. 15 No. 4, pp. 603-626.

Gilding, M., Gregory, S. and Cosson, B. (2015), "Motives and outcomes in family business succession planning”, Entrepreneurship Theory and Practice, Vol. 39 No. 2, pp. 299-312.

Granovetter, M. (1985), "Economic action and social structure: The problem of embeddedness", American Journal of Sociology, Vol. 91 No. 3, pp. 481-510.

Grant, R.M. (1996), “Towards a knowledge-based theory of the firm”, Strategic Management Journal, Vol. 17, pp. 109-122.

Handler, W.C. (1994), "Succession in Family Business: A review of the research", Family Business Review1, Vol. 7 No. 2, pp. 133-157.

Hatak, I.R. and Roessl, D. (2015), "Relational Competence-Based Knowledge Transfer Within Intrafamily Succession: An Experimental Study”, Family Business Review, Vol. 28 No. 1, pp. $10-25$.

Hofestede, G. (2001). Culture's Consequences: Comparing values, behaviors, institutions and organizations across nations. $2^{\text {nd }} E d$. SAGE Publications, London.

Hofstede, G. (1980), Culture's Consequences: International Differences in Work-Related Values. SAGE Publications, London.

Janjuha-Jivraj, S., \& Woods, A. (2002), "Successional issues within Asian family firms: Learning from the Kenyan experience", International Small Business Journal, Vol. 20 No. 1, pp. 77-94.

Jankowicz, A.D. (2005), Business Research Projects, Cengage Learning EMEA.

Jaskiewicz, P., Heinrichs, K., Rau, S.B. and Reay, T. (2016), "To be or not to be: How family firms manage family and commercial logics for succession", Entrepreneurship Theory and Practice, Vol. 40 No. 4, pp. 781-813

Javidan, M., House, R.J., Dorfman, P.W., Hanges, P.J. and Sully de Luque, M. (2006), "Conceptualizing and measuring cultures and their consequences: A comparative review of GLOBE's and Hofstede's approaches”, Journal of International Business Studies, Vol. 37 No. 6, pp. 897-914

Kloosterman, R., van der Leun, J.P. and Rath, J. (1999), "Mixed embeddedness, migrant entrepreneurship and informal economic activities", International Journal of Urban and Regional Research, Vol. 23 No. 2, pp. 253-267.

LeBreton-Miller, I.L., Miller, D. and Steier, L.P. (2004), "Toward an integrative model of effective FOB succession", Entrepreneurship Theory and Practice, Vol. 28 No. 4, pp. 305328.

Lin, W-B. (2013), "Research on knowledge sharing and interpersonal relationships: empirical study of family firms and non-family firms", Quality \& Quantity, Vol. 47 No. 1, pp. 151-166. 
Long, R.G. and Chrisman, J.J. (2014), Management succession in family business. In L.Melin, M.Nordqvist, \& P.Sharma (Eds.), Sage handbook of family business (pp. 249-268). Thousand Oaks, CA: Sage.

Long, R.G. and Mathews, K.M. (2011), "Ethics in the family firm: Cohesions through reciprocity and exchange", Journal of Business Ethics, Vol. 21, pp. 287-308.

Martin, L. (2001), "More jobs for the boys? Succession planning in SMEs", Women in Management Review, Vol. 16 No. 5, pp. 222-231.

Mazzola, P., Marchisio, G. and Astrachan, J. (2008), "Strategic planning in family business: A powerful developmental tool for the next generation”, Family Business Review, Vol. 21 No. 3, pp. 239-258.

McAdam, R. and Reid, R. (2001), "SME and large organisation perceptions of knowledge management: comparisions and contrasts", Journal of Knowledge Management, Vol. 5 No. 3 , pp. 231-241.

McSweeney, B. (2002), "Hofstede's model of national cultural differences and their consequences: A triumph of faith-a failure of analysis", Human Relations, Vol. 55 No. 1, pp. 89-118.

Nonaka, I. and Takeuchi, H. (1995), The knowledge-creating company: how Japanese companies create the dynamics of innovation, Oxford: Oxford university press.

Nordqvist, M., Wennberg, K. and Hellerstedt, K. (2013), “An entrepreneurial process perspective on succession in family firms", Small Business Economics, Vol. 40 No. 4, pp. 1087-1122.

Nunes, M.B., Annansingh, F., Eaglestone, B. and Wakefield, R. (2006), "Knowledge management issues in knowledge-intensive SMEs", Journal of Documentation, Vol. 62 No. 1, pp. 109-128.

Pearson, A.W., Carr, J.C. and Shaw, J.C. (2008), "Toward a theory of familiness: a social capital perspective", Entrepreneurship Theory and Practice, Vol. 32 No. 6, pp. 949-969.

Pieper, T.M. and Klein, S.B. (2007), "The bulleye: a systems approach to modelling family firms", Family Business Review, Vol. 20 No. 4, pp. 301-319.

Ram, M. and Jones, T. (2008), "Ethnic-minority businesses in the UK: a review of research and policy developments", Environment and Planning C: Government and Policy, Vol. 26 No. 2, pp. 352-374.

Randerson, K., Bettinelli, C., Fayolle, A. and Anderson, A.R. (2015), "Family entrepreneurship as a field of research: Exploring its contours and contents", Journal of Family Business Strategy, Vol. 6 No. 3, pp. 143-154.

Royer, S., Simons, R., Boyd, B. and Rafferty, A. (2008), "Promoting family: A contingency model of family business succession”, Family Business Review, Vol. 21 No. 1, pp. 15-30.

Schulze, W.S., Lubatkin, M.H., Dino, R.N. and Buchholtz, A.K. (2001), “Agency relationships in family firms: Theory and evidence”, Organization Science, Vol. 12, pp. 99-116. 
Seaman, C., Bent, R. and Unis, A. (2015), "Family entrepreneurship culture, entrepreneurial intent, futures and foresight in Scottish Pakistani communities", Futures, Vol 75, pp. 83-91.

Shaiq, H.M.A., Khalid, H.M.S., Akram, A. and Ali, B. (2011), "Why not everybody loves Hofstede? What are the alternative approaches to study of culture", European Journal of Business and Management, Vol. 3 No. 6, pp. 101-111.

Sharma, P. (2004), "An overview of the field of family business studies: Current status and directions for the future", Family Business Review, Vol. 17 No. 1, pp. 1-36.

Sharma, P. and Chua, J.H. (2013), “Asian family enterprises and family business research", Asia Pacific Journal of Management, Vol. 30 No. 3, pp. 641-656.

Sharma, P. and Rao, A.S. (2000), "Successor attributes in Indian and Canadian family firms: A comparative study”, Family Business Review, Vol. 13, pp. 313-330.

Sharma, P., Chrisman, J.J., Pablo, A.L. and Chua, J.H. (2001), "Determinants of Initial Satisfaction with the Succession Process in Family Firms: A Conceptual Model.", Entrepreneurship Theory \& Practice, Vol. 25 No. 3, pp. 17-35.

Shi, H.X. and Dana, L.P. (2013), "Market orientation and entrepreneurship in Chinese family business: a socialisation view", International Journal of Entrepreneurship and Small Business, Vol. 20 No. 1.

Shi, H.X., Shepherd, D.M. and Schmidts, T. (2015), "Social capital in entrepreneurial family businesses: the role of trust", International Journal of Entrepreneurial Behavior \& Research, Vol. 21 No. 6, pp. 814-841.

Short, J.C., Sharma, P., Lumpkin, G.T. and Pearson, A.W. (2016), "Oh, the Places Well Go! Reviewing Past, Present, and Future Possibilities in Family Business Research", Family Business Review, Vol. 29 No. 1, pp. 11-16.

Sirmon, D.G. and Hitt, M.A. (2003), "Managing resources: linking unique resources, management, and wealth creation in family firms", Entrepreneurship Theory and Practice, Vol. 27 No. 4, pp. 339-358.

Steier, L.P. and Miller, D. (2010), "Pre-and post-succession governance philosophies in entrepreneurial family firms", Journal of Family Business Strategy, Vol. 1 No. 3, pp. 145-154.

Szulanski, G. (1996), "Exploring Internal Stickiness: Impedimens to the Transfer of Best Practice Within the Firm”, Strategic Management Journal, Vol. 17, pp. 27-43.

Tatoglu, E., Kula, V. and Glaister, K.W. (2008), "Succession planning in family-owned businesses: Evidence from Turkey", International Small Business Journal, Vol. 26, pp. 155180.

Venter, E., Boshoff, C. and Maas, G. (2005), "The influence of successor-related factors on the succession process in small and medium-sized family businesses", Family Business Review, Vol. 18 No. 4, pp. 283-303.

Vera, C.F. and Dean, M.A. (2005), “An examination of the challenges daughters face in family business succession”, Family Business Review, Vol. 18 No. 4, pp. 321-345. 
Welter, F. (2011), "Contextualizing entrepreneurship-conceptual challenges and ways forward”, Entrepreneurship Theory and Practice, Vol. 35 No. 1, pp.165-184.

Xi, J., Kraus, S., Filser, M. and Kellermanns, F.W. (2014), "Mapping the field of family business research: past trends and future directions", International Entrepreneurship and Management Journal, Vol. 11 No. 1, pp. 113-132.

Yan, J. and Sorenson, R. (2006), "The effect of Confucian values on succession in family business", Family Business Review, Vol. 19 No. 3, pp. 235-250.

Yin, R.K. (2014), Case Study Research: Design and Methods, Sage publications.

Zellweger, T., Sieger, P. and Halter, F. (2011), "Should I stay or should I go? Career choice intentions of students with family business background", Journal of Business Venturing, Vol. 26 No. 5, pp. 521-536. 